Insa Theesfeld* and Frederike Klümper

\title{
Interplay between structural change in Central Asian agriculture and institutional scarcity of land and water: evidence from Tajikistan
}

\section{DOI 10.1515/zfw-2016-0003}

Abstract: This contribution focuses on the interaction between structural change in agriculture and the availability of key natural resources - land and water. The relationship is not unidimensional; therefore, we propose three dimensions of resource-induced structural change. The first dimension describes the links between the two critical input factors into agricultural production, namely land and water. To systematize this perspective, we use the concept of linking patterns that depict direct and indirect intersectoral linkages from a property rights perspective. Second, we examinee the dimension of how structural change in agriculture can be triggered by scarcity of natural resources. The third dimension describes structural change that may lead to overuse and scarcity. In this regard, we introduce resource scarcity not only as physical but most important as institutional scarcity. To illustrate these dimensions, we have chosen a case in Central Asia, where the availability and the control of access and withdrawal rights to land and water is of utmost importance for the agricultural sector. Tajikistan faces physical and institutional scarcity in arable land. The institutional scarcity is due to the non-transparent and costly processes that need to be followed to gain land rights. Likewise there is sufficient supply in water, in Tajikistan, but the de-facto access rights to water are limited for some groups. For instance, the post-socialist irrigation infrastructure is now inappropriate to serve all small-scale users on a canal. In the future, land use change due to a predicted increase of major investors, will have additional impact on the de-facto water rights. We conclude that a solid study not only on the physical but also on the institutional relations of agriculture to natural resources is important to come to reliable predictions of structural change in agriculture. We also show that structural change in agriculture may have

\footnotetext{
*Corresponding author: Insa Theesfeld, Institut für Agrar- und Ernährungswissenschaften, Martin-Luther-Universität Halle-

Wittenberg, Von-Seckendorff-Platz 4, 06120 Halle (Saale), Germany, e-mail: insa.theesfeld@landw.uni-halle.de

Frederike Klümper, Leibniz-Institut für Agrarentwicklung in Mittelund Osteuropa, Halle, Germany
}

wider implications for rural society that go beyond the agricultural sector.

Keywords: Central Asia, institutional scarcity, land and water, property rights, structural change.

\section{Introduction}

In this contribution we focus on the interaction of natural resource availability with structural change in agriculture. We will concentrate on the resources land and water, i.e. the main "raw materials" in the agricultural sector. Our key argument is that the relationship is not unidimensional. In fact, structural change in agriculture can be triggered by natural resource scarcity, but likewise structural change may lead to a certain form of resource use or management, in turn leading to overuse and scarcity. Fundamentally we understand resource scarcity not only as physical scarcity but also as institutional scarcity, which refers according to Sadoff et al. (2006) to insufficient distribution and implementation of rights leading to the resource inadequate access. We have chosen to discuss this concept in the context of Central Asia, where the availability and the control of access and withdrawal rights in natural resources is of utmost importance for the agricultural sector. Therefore, although we draw our empirical material from Tajikistan, the conclusions hold for the Central Asia region and other transition countries with similar land and water reform pathways.

In this paper, we use a concept that facilitates a systematic study of the direct and indirect intersectoral linkages between land and water. This concept of linking patterns is based on a property rights perspective (Theesfeld 2016). It helps to identify the institutional scarcities accompanying with emerging developments, such as increases in global land deals, that in turn cause structural changes in agriculture. 


\section{Structural change in agriculture}

A classical definition of structural change in agriculture encompasses the change in number, size and legal forms of agricultural farms and their production structure (Specht 2013). This definition involves no normative requirement regarding either the pace and extent, or the direction of development. Some definitions also include the share of agricultural labour on a farm. Chavas (2001) further specifies that, for developed countries, a decrease of labour and specialisation especially indicates structural change in agriculture. Broader definitions from Kirschke et al. (2007) define agricultural change as the changing societal demands for environmental goods, animal welfare and multifunctionality. In this paper, drawing on Specht (2013), Knickel (1990) and Chavas (2001), we define structural change in agriculture as a long-term transformation in agriculture-related structures, namely farm types and farm size including structurally-induced changes in cropping patterns and land use.

The transformation of agricultural production structures has been a phenomenon in most transition countries after the break down of the former Soviet Union. On the one hand, these structural changes triggered many challenges for most of the related countries, for instance in the land sector, the input sector, or on the agricultural credit market (Verdery 2003, Swinnen and Rozelle 2006). However, the implementation and thus the impact of structural change in agriculture have been very different among Eastern Europe, Central Asia and the Caucasus (Hofman and Visser 2014). The countries involved typically try to actively steer the agricultural change in certain directions by politically induced reforms in the land and water sector. In Central Asia, where agricultural land and water reforms were introduced after 1990, the extent and the speed of implementing such reforms have been diverse. Interestingly in Tajikistan, the poorest of the Central Asian nations, implementation varies a lot even within the country due to its geographic diversity (Hofman and Visser 2014; Robinson et al. 2008). Moreover, land and water sectoral reforms continuously changed, and were even interrupted by a civil war in the 1990s.

\subsection{Structural change in Tajikistan's agricul- tural sector}

The result of the transformation process of the post-socialist countries resembles a major structural change in agriculture. As in other transition countries, one result in Tajikistan is the privatization of former state and collective farms into private family farms. Intended as commercial farming units, the so called "dekhan farms" have an average size of about $12.1 \mathrm{ha}^{1}$ according to recent figures. In addition, many small-scale farm types such as household gardens and presidential farms ${ }^{2}$ exist, mainly as subsistence farms with an average farm size of 0.3 ha (Akramov and Shreedhar 2012). Although household farming already existed during the Soviet period, its share of arable land as well as its importance in gross agricultural output very much increased from 1997 to 2014 (see Table 1 and Figure 1). In the beginning of the land reform the reallocation process was very slow and until 2007 only $45 \%$ of the arable land had been restructured (Akramov and Shreedhar 2012). Since 2007 land restructuring policy has been more strongly enforced, and in 2013 almost $60 \%$ of the arable land has been used by dekhan (family) farms. Collective farms now exist only on paper.

Akramov and Shreedhar (2012) further emphasize the regional importance of the two agricultural districts Khatlon and Soghd. Those two districts produce about $60 \%$ of the country's total gross agricultural output (GAO). In total the GAO of Tajikistan has doubled between 1997 and 2008 (Lerman 2012). Figure 1 shows the share of GAO distributed among the three main different farm types. Household plots produce about $70 \%$ of the GAO on only $22 \%$ of the arable land, and thus are the most productive agricultural unit.

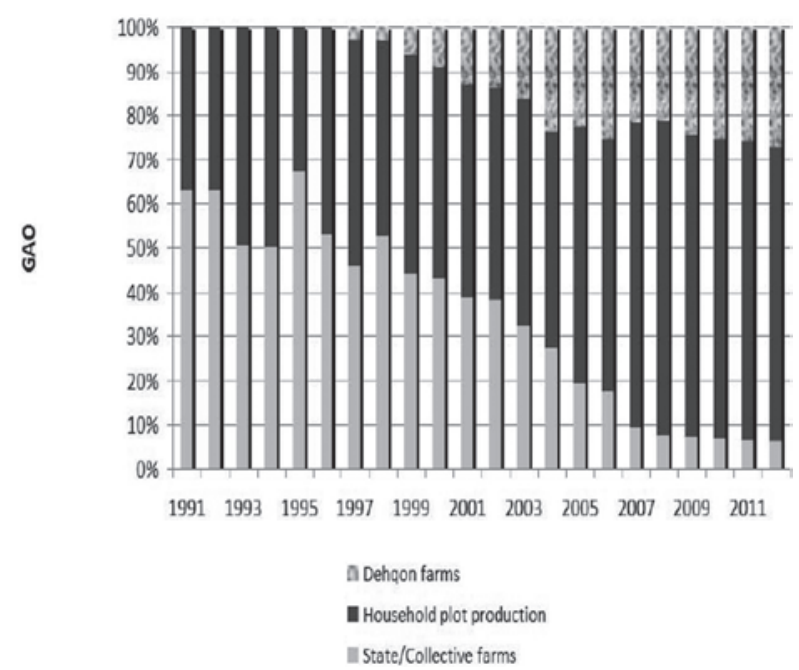

Figure 1: Gross agricultural output by farm type. Source: Hofman and Visser (2014).

1 This figure varies between the different regions. In mountainous regions the dekhan farms are larger on average.

2 In 1995 and 1997, the government allocated agricultural land (mainly unused or marginal lands) to the very poor households - in total, 75000 ha. 
Table 1: Numbers and share of arable land by farm type.

\begin{tabular}{|c|c|c|c|c|}
\hline & & $1996 / 1997$ & $2006 / 2007$ & $2012 / 2013 / 2014$ \\
\hline \multirow[t]{2}{*}{ State- and Collective Farms } & Number & $715^{a}$ & $59^{a}$ & \\
\hline & Share of total arable land & & $29.5 \%^{b}$ & $19.9 \%^{b}$ \\
\hline \multirow[t]{2}{*}{ Dekhan Farms } & Number & $8023^{a}$ & $24901^{\mathrm{a}}$ & $108035^{\mathrm{a}}$ \\
\hline & Share of total arable land & $0.5 \%^{a}$ & $49.9 \%{ }^{b}$ & $59.3 \%^{b}$ \\
\hline \multirow[t]{2}{*}{ Household Plots } & Number & & $740000^{c}$ & $825000^{c}$ \\
\hline & Share of total arable land & & $20.6 \%^{b}$ & $22.7 \%^{b}$ \\
\hline
\end{tabular}

Note: The limits of data availability do not allow for a complete overview. Data are not always available from a consistent source or for each year. Shares in total arable land are calculated from TAJStat (2012).

Sources: ${ }^{\mathrm{a}}$ TAJStat (2015), ${ }^{\mathrm{b}}$ TAJStat (2012); ${ }^{\mathrm{c}}$ Akramov and Shreedhar (2012).

Table 2: Demographic development in Tajikistan.

\begin{tabular}{lrrrrr}
\hline & $\mathbf{1 9 9 2}$ & $\mathbf{2 0 0 0}$ & $\mathbf{2 0 0 7}$ & $\mathbf{2 0 1 3}$ & 2020 (est.) \\
\hline Rural population (in 1000s) & 3837 & 4548 & 5230 & 6024 & 6957 \\
Economically active population in agriculture (in 1000s) & 731 & 611 & 792 & 897 & 937 \\
Total population (in 1000s) & 5523 & 6186 & 7099 & 8111 & 9419 \\
Share of rural population in total population & $69 \%$ & $73 \%$ & $73 \%$ & $74 \%$ & $73 \%$ \\
\hline
\end{tabular}

Source: authors' compilation based on FAO (2015c).

Most individual farmers were previously shareholders and farm workers at a collective farm, and therefore have less managerial and business skills. That fact challenges the outcome of the agricultural sector development (USAID 2014). After independence, the total number of the economically active population in agriculture dropped (due to restructuring and civil war). Since 2000 this population has continuously increased, a trend which is also related to the overall weak economic development. In parallel with the total population growth, the share of the rural population in the total population remains at a high level (Table 2).

Summing up, the legal reforms led to a structural change in 1) numbers of private farms which increased and 2) farm size and type change from large-scale collectives to small-scale private farms.

\subsection{Change in land use}

In addition to changes in legal farm structure, farm size and number of farms, we can also observe a change in land use patterns. Knickel (1990) states that structural change in agriculture is also characterized by specialization in farm units and crops. In Tajikistan in contrast, the de-collectivization and smaller farm units rather fostered a diversification of crop production. The total cropping sector very much decreased in terms of crop area harvest- ed and production after 2003; it is now slowly recovering for some crops (FAO 2015c). Among all the crops produced in Tajikistan, it is important to stress the role of cotton production in the country. During the Soviet Union period, Tajikistan was one of the central cotton producing countries with vast irrigation physical infrastructure for that purpose. Most kolkhozes and sovkhozes - the former collective and state farms, respectively - were mainly concentrating on cotton production and processing. After the breakdown, the cotton sector in particular faced several constraints due to the absence of financial and technological state-support (van Atta 2009). But despite the ongoing low productivity and challenges in the cotton sector, production continues. According to Akramov and Shreedhar (2012, p.12), about $20 \%$ of the sown area was cultivated with cotton in 2009.

Compared to cotton, the wheat area harvested ${ }^{3}$ - as well as its total production output - very much increased in the early 1990s. Especially after 1995, the harvested wheat area very much increased. Figure 2 exemplifies the main land use change from cotton to wheat as well as other crops in the transition phase. From the selected main crops produced in Tajikistan, wheat is produced on almost $50 \%$ of the crop area harvested. On average, one dekhan

3 The area harvested incorporates the fact that due to such factors as weather extremes, the area sown does not every year equal the area that could be harvested at the end of a season. 
farm has an area of about 3.5 ha of wheat; however, this varies a lot between the regions (GBAO 25, 4 ha, Soghd 4.5 ha, Khatlon 3,8 ha, Hissar 1,4 ha, Vahdat 1,0 ha) (TAJStat 2012, p. 156 ff). Another interesting production increase can be observed for potatoes. The share of potato area harvested from all selected crops increased from about $2 \%$ in 1992 to about $9 \%$ in 2012. The area harvested of fresh vegetables, tomatoes and rice varies a lot between the years, but is also slightly increasing in total numbers. In 2012 $22.9 \%$ of all vegetables were produced in the Soghd region (Akramov and Shreedhar 2012). This indicates an initial step in the change from centralized cotton production on state and collective farms for export towards more diversified production on smaller-scale plots for subsistence and local markets.

Overall, there is of course a big difference of land use between the uplands and lowlands. In the uplands, mainly rainfed agriculture is dominant and mainly less water-intensive crops are produced. Uplands agriculture suffers from very marginal lands and degradation due to over-grazing and deforestation. In the lowlands, however, where the big irrigation systems were constructed during the Soviet time for cotton production, irrigated agriculture still dominates. In these irrigated areas crop planting even takes place two to three times a year. As we focus on the interface between land and irrigation water, we mainly refer to the lowland regions with irrigated agriculture. The empirical evidence from Tajikistan is based on qualitative findings from fieldwork in 2013 in the Khatlon province (Gehrigk et al. 2013). The study focused on one part of the Amu Darya basin in the district Bokhtar where the agricultural structure is twofold. Large cotton farms and small household plots dominate the irrigation-intense agricultural sector. Also the additional case study described in Chapter 4.2 was conducted in the southern lowland regions of Tajikistan (district Bokhtar, see Figure 3.

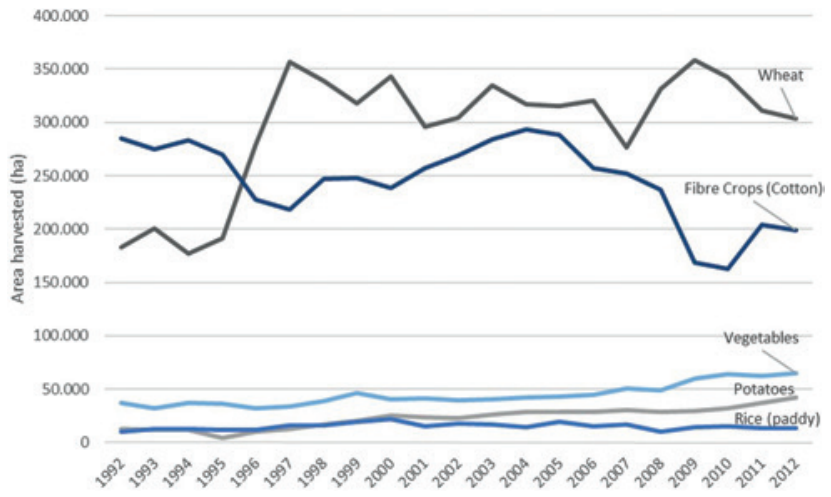

Figure 2: Crop area harvested in hectares in Tajikistan (national level). Source: authors' compilation based on FAO (2015c).

\section{Scarcity concepts for land and water}

Following Sadoff et al. (2006), the growing scarcity of natural resources can be seen not only as a challenge of physical resource scarcity, but as a challenge of economic and institutional scarcity as well. Physical resource scarcity is defined as the amounts of non-renewable resources that are being depleted, and where consequently users face an un-desired lack of resources over time. Institutional scarcity concentrates on the rules and regulations that determine access rights. It implies that even when physical and infrastructural resources are sufficient, unresolved conflicts over rights, insufficient or unequally distributed rights, governance mechanisms, or social structures may nonetheless lead to situations where not all members of society have adequate access to land or water (Sadoff et al. 2006, p.13).

Having physically enough resources but being denied access is for certain groups a consequence of social, cultural or political processes. Such causalities are likewise studied by scholars of political ecology (Ribot and Peluso 2003). The processes that prevent resource access encompass many more social and cultural factors that lead to scarcity than the comparatively narrow concept of institutional scarcity can grasp. For instance Mbereko et al. (2015) analyze a situation in Zimbabwe where land more precisely wetland - is still available but due to new production structures fewer families have access to it. The political ecology framework allows studying how local water rights have been marginalized, which de facto leads to institutional scarcity. At a national and regional level, Walsh (2004) studies the historical and political situations driving the border water conflicts between Mexico and the U.S. at the Rio Bravo River. Also Walsh explores the idea that another cause of resource scarcity is political bargains that deny water rights. Indeed political bargains denying resource rights tend to develop in situations where the resource involved is already physically scarce. For the Central Asian region, Wegerich (2011) provides several insights into the politics of transboundary water distribution, such as for the Amu Darya river shared by Tajikistan and Uzbekistan and experiencing several severe droughts since 2000. The unequal and more severe water scarcity in the downstream regions of the river basin is described by Wegerich (2011, p.9) as not only triggered by natural factors but also by changes in water allocation based on political decisions, such as the political agenda of Uzbekistan to make cotton production the highest priority for export. Our focus here is indeed not to analyze the politics behind 
Tajikistan

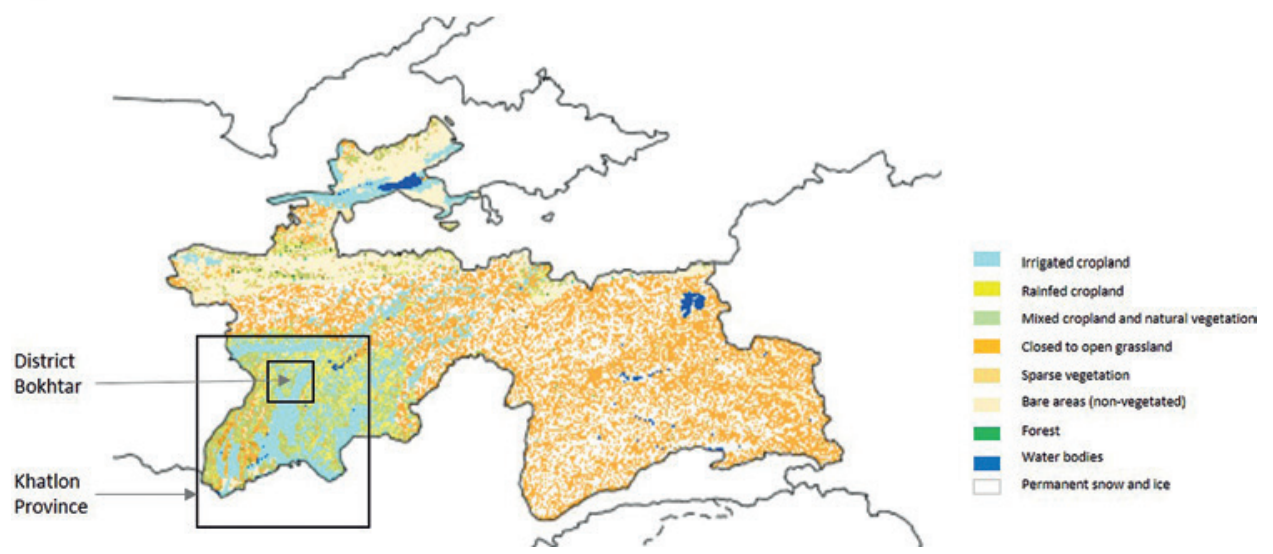

Figure 3: Land Cover Map Tajikistan indicating the study area. Source: adapted from: http://www.fao.org/countryprofiles/maps/map/en/?iso3=TJK\&mapID=609.

the changes in the formal and informal bundles of property rights in Tajikistan or to examine in detail the power relationships that reinforce inequities in decision-making and access rights (Ribot and Peluso 2003; Mbereko et al. 2015). We are concerned with the need for a joined consideration of both land and water rights, which is also rare in political ecology studies. Further, we want to show how the various scarcities affect structural change in the agricultural sector. Besides the right of access to a resource, we include in our analysis of scarcities the other bundles of property rights, which Schlager and Ostrom (1992) specify as withdrawal, management, exclusion and alienation.

\subsection{Physical scarcity of land}

Arable land suitable for agricultural production in Tajikistan is naturally very limited. As a very mountainous country, only about $7 \%$ of the total land area is arable. Salinization is further decreasing the availability of farm land. Therefore, there is a need for sustainable land use and good land governance. The amount of arable land changed from previous 860000 ha in 1992 to 746000 ha in 2007. In 2012 however, 860000 ha of arable land was reported again (FAO 2015b). In principle, since the breakdown of the Soviet Union all individuals can get a share of farm land from either land which is classified as unused, or from former collective and state farms. According to the land law, this right is not only limited to farmers but to all Tajik nationals. The current government reform program seeks to divide available land among individual farmers even more effectively in coming years than it has in the past (Hofman and Visser 2014). For those interested in commercial farming, arable land still poses a limit of growth. Based on the very limited arable land available per person (FAO 2015c), we expect that increasing one's farm size is difficult due to competition and is only possible if other farmers drop out of agriculture.

\subsection{Institutional scarcity of land}

Since the breakdown of the Soviet Union, farm land in Tajikistan has been considered state property. For Tajiks and for foreigners it is only possible to lease land to get use rights. According to the actual Land Code foreigners can only lease state owned land for up to 50 years, whereas local citizens can gain unlimited use rights, which is heritable. In either case, the holder of the use rights receives a land certificate. Official land transfers have to be in line with the Land Code and undertaken by the Land Committee, which is the decisionmaking authority for all land related issues. These committees operate at a decentralized, district level. Especially since 2009, as the World Bank (2012) reported, the issuance of land certificates has increased. However, on the local level, the process of accessing land is more complex and restricted by various factors. Mandler (2013) addresses, for instance, farmers' lack of knowledge of key factors, such as the administrative process of getting land use certificates. He further analyzes the importance of local officials or elites in the community that have an influence on the land allocation process. Further, as the World Bank (2012) report has shown, farmers sometimes simply cannot afford the certification process, due to high fees required for applications. Therefore the land allocation processes are often classified as long, 
costly and very non-transparent (Robinson and Guenther 2007, Robinson et al. 2008). This shows that in addition to the limited physical availability, the user rights themselves are also restricted and controlled.

Having taken into account these classical transformation processes, we now want to discuss a particular aspect of resource scarcity. We need to consider that the control over the land resource may very likely change once more in the future, which can lead to a particular form of institutional scarcity in land. This is due to the global trend, the "rush for land", which Visser and Spoor (2011) predict will also affect the Central Asian region. The early trend can already be observed in Tajikistan. Both Tajik farmers and foreigners increasingly seek rights to agricultural land in the lowland areas. Insights to foreign land acquisitions in the southern province of Tajikistan, Khatlon can be gleaned from media reports and an initial study done by Hofman (2013). Foreign land acquisitions, involving leases of between 45 - 550 ha, exceed the average private farm size of 30 ha in an area of very limited arable land and increasing population density. Too little is yet known about foreign large-scale land-acquisition in Tajikistan. In the frame of our own fieldwork, however, we also observed a case of Chinese investment in substantial numbers of hectares.

There are two factors that particularly lead to an institutional scarcity of land. First, the aim of allocating land to an enlarged group of beneficiaries makes it de facto scarce for the few who have real local entrepreneurial potential. Second, the practice of non-transparent allocation of land classified as unused, as reported by interviewees in the Bokhtar district, reduces the de-facto access rights of those without connection to relevant knowledge networks. The emerging processes of land acquisition and a corresponding change in land tenure rights will have additional impact on the agricultural structures.

\subsection{Physical abundance of water}

Besides land suitable for farming, water resources are the key production factor for agriculture, a factor which is ever more demanded for food and biofuel production for the growing population. Especially in Central Asia, the Aral Sea basin is known for its intensively irrigated agriculture and its growing environmental problems of physical water scarcity which especially threaten the agricultural sector (Wegerich 2002). Along the main rivers, Syr Darya and Amu Darya, land is irrigated intensively. Tajikistan is one of the upstream countries of the two rivers and thus one of the main water suppliers for the entire basin. Together with the two Southern river basins of the Syr Darya and the Amu Darya, the Zeravshan basin in the central part of the country make Tajikistan a physically water rich country. In all of the lowlands in the three river basins, the share of actually irrigated land is between $50-75 \%$. Around $60^{10^{\wedge 9}} \mathrm{~m}^{3} /$ year surface water in the area is river water inflow, the major portion of the total renewable water resources of to $633^{10^{\wedge}} \mathrm{m}^{3} /$ year (FAO 2013; FAO 2015a). On average, precipitation rates are also high, at $691 \mathrm{~mm}$ per year; however this varies a lot between the regions and the year. The lowlands, the main agricultural areas, have very low precipitation rates in the cropping season. Therefore, about $90 \%$ of the total area is equipped for irrigation and $90 \%$ of the total water withdrawal is used for agriculture (see Figure 3). Most of the water (93\%) used for irrigation is surface water (FAO 2013).

Looking at water problems from the hydrological point of view, two contrary situations can be identified. On the one hand, Tajikistan is very vulnerable to floods and landslides caused by high rainfall and meltwater in springtime in the mountainous areas. On the other hand, within the irrigation catchment areas, water is used to such a large extent that it can easily become scarce during the cropping season. If this scarcity occurs due to mismanagement or unsuitable governance systems, we define this as institutional scarcity.

Land use change decisions may result in crop decisions which are not suitable for the given water availability, infrastructure and management structures. As depicted in Figure 4, the harvested irrigated cotton area has decreased, whereas the irrigated wheat area has increased. In addition, the harvested vegetable and rice areas have increased and require considerably more irrigation water compared to cotton and wheat.

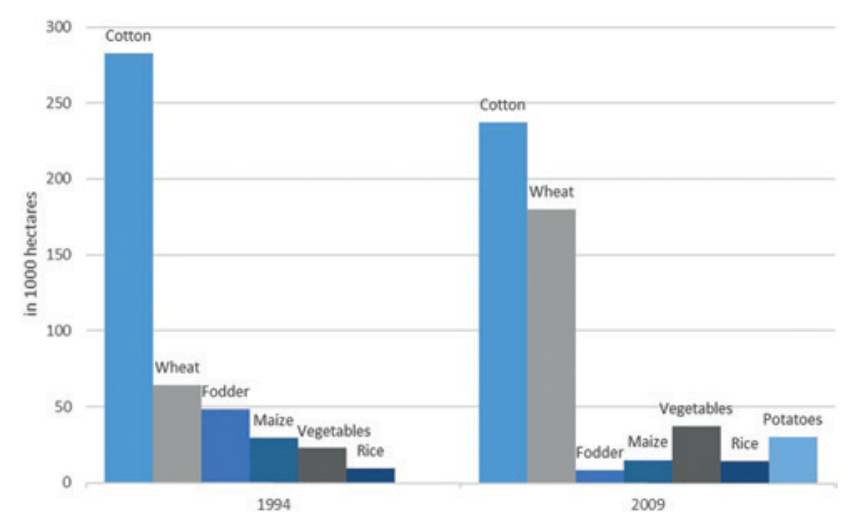

Figure 4: Harvested irrigated temporary crop area in Tajikistan (national level). Source: authors' compilation based on FAO (2015a). 


\subsection{Institutional scarcity of water}

In sum, water is apparently abundant in Tajikistan, but we observe a form of institutional scarcity in the irrigation sector. This is in the first instance due to the increase in individual small-scale farmers resulting from the agricultural structural change. More small-scale farms require a different irrigation system, in terms of both technology and governance.

Structural and organizational reforms in the irrigation sector have been partly responsible for increasing the institutional scarcity of water. Availability of water in sufficient quantity and quality with a reliable supply system is not always given. Since 1990 the Tajik irrigation sector has changed considerably, especially with respect to administrative responsibilities. The former centrally-planned and -managed irrigation systems have been replaced, but still follow a hierarchical order, where major strategies and reforms are decided at national level, while other decisions are made by the many governmental organizations now involved in Tajikistan's irrigation sector. Water authorities at state, province and district level are responsible for planning and management of water distribution and delivery to the farm inlet. Larger-scale irrigation infrastructure is expected to be operated and maintained by governmental water authorities. At the district and community level, water user associations (WUAs) are being slowly introduced to organize the water supply between the supply-ditch head-gates and the farm level. The areas where WUAs are actively involved in water management are increasing but are still below the projected aims. In 2013, they covered $35 \%$ of irrigated areas (AQUASTAT 2013).

Meanwhile, the physical irrigation infrastructure has largely deteriorated, which demands huge investments. So far, water fees paid by farmers do not, by far, cover the costs of the investment needed. As a result, the water management organizations are unable to provide water in due time. That, in turn, disrupts the maintenance schedule for drainage facilities, too. Institutional scarcity in the irrigation sector emerged as more individual farmers have accessed the irrigation canals. During the Soviet time, cooperation in water management was hardly needed. Now, however, a new governance strategy is needed. Sustainable water distribution which is regarded as fair at local scale depends on collective decision-making among farmers and is even more needed as cropping patterns become more diverse. The implementation of cooperation is however challenged at two levels. First, it is hampered within communities, because farmers have different perceptions about water access rights. In communities where the elites still claim the decisionmaking power, farmers are less willing to cooperate in canal management. In addition, our interviews have revealed that, especially in situations of conflict, farmers approach different people to work out their water management problems. They confer and negotiate not only with bureaucratic authorities, but also with large-scale farmers. Thus accountability for the final decisions is often non-transparent. Second, communities face difficulties in collaborating with each other on irrigation matters, since different ecosystem and infrastructural conditions lead to high heterogeneity in water supply. Further, quite diverse strategies of irrigation regimes during water shortages may be implemented in neighbouring communities, likewise making collaboration difficult. Insufficient cooperation between communities is known for governance less adapted to local needs and for denial of fair access to all groups (Ostrom 1992). Overall, the factors that hamper collaboration lead to institutional scarcity of water. The dekhan farms suffer the most, because they have to allocate water further among themselves, which requires more collective decision makings. Meanwhile they struggle with the problem that the irrigation systems they must use have been constructed for large-scale farms.

\section{Interrelations between natural resource scarcity and agricultural structural changes}

We will subdivide the interrelations between natural resource scarcity and structural changes in the agricultural sector into three dimensions. Just like land, water is a critical input factor into agricultural production and thus, the interconnectedness of the two resources needs to be disentangled. The first dimension specifies how the resources themselves are interrelated due to the bio-physical and institutional jointness of the transactions involving the resource. The second dimension highlights the fact that it is institutional scarcity of a natural resource, in particular, that can lead to further agricultural structural change. The third dimension points out how structural change in agriculture, (including farm numbers, sizes, types and land use) in turn affects land and water availability. 
Table 3: Three dimensions of resource-induced structural change.

\begin{tabular}{lcl}
\hline $\begin{array}{l}\text { Dimensions of resource-induced structural change in the } \\
\text { agricultural land and water sector }\end{array}$ \\
\begin{tabular}{lll} 
1. Resource & 2. Institutional & 3. Agricultural \\
interlinkages in & scarcity and & structural \\
the agricultural & agricultural & $\begin{array}{l}\text { change and } \\
\text { resource } \\
\text { sector }\end{array}$ \\
& structural change & availability \\
\hline
\end{tabular}
\end{tabular}

Source: authors' compilation.

\subsection{Patterns of linkage between land and water}

The first dimension of investigating resource-induced structural change in the agricultural sector requires concentrating on the links between the two critical input factors into agricultural production, namely land and water. We will do so, by drawing from the concept of linking patterns which has been developed from a property rights perspective (Theesfeld 2015, Theesfeld 2016). This concept makes it possible to look at evolving institutional scarcities of water due to an initial change in property rights to land. There are many different ways in which access or withdrawal rights to water can be obtained or lost, triggered by general land redistribution processes or by foreign land acquisition processes. Moreover, there are many ways those rights can be exercised. What works depends very much on local conditions. Investors' approaches to water rights acquisition can range from careful advance planning with open discussion to unannounced misappropriation of water after the land deal is completed. The concept of linking patterns likewise helps to underline the fact that persons who possess the control over land resources do also control water resources to a large extent.

Empirically, up to now, the effects that a change in property rights on land has on property rights on water at a local scale have hardly been studied in the area under consideration. A first notion of the interlinkages involved has been addressed in the land- and water grabbing debate. A solid consideration of these issues is however a precondition if we want to make predictions about impacts on the agricultural and societal structures that can be initially triggered by such developments as larger-scale investments in land.

Derived from known land-grabbing cases, eight patterns in the connection between land and water acquisition have been identified and will be applied here as potentially important factors to consider: 1) the ecological pattern, 2) the judicial pattern, 3) the resettlement pattern,
4) the use pattern, 5) the land use pattern, 6) the conjunctive use pattern, 7) the infrastructure pattern and 8) the governance pattern (Theesfeld 2016). Attention to the patterns allows a researcher to classify the impact of land acquisition on the various rights and claims in the agricultural water sector. The proposed eight patterns strengthen a comprehensive and systematic study of the particular interrelationships between the scarcity of land and water. Most of these patterns can be identified in the case of Tajikistan, in terms of the general land restructuring process as well as in one specific foreign land acquisition case, as described in the next subchapter.

Table 4 summarizes and depicts core questions for each pattern and the particular change it can effect in certain bundles of property rights based on Schlager and Ostrom (1992). Each pattern does implicitly show that it is not the right or claim that links the land and water sector, but the transaction related to nature that is involved (Hagedorn 2008). According to the functional interdependence of the process, the water has to be physically at the same spot where the agricultural production happens on the land. The underlying interconnectedness of the transactions related to nature (Hagedorn 2008, p. 359) is easy to grasp in considering items such as the land use pattern, where different biophysical condition of a crop require different amounts and quality of water to maximize crop yield. Water either has to be available or has to be moved with the help of technical infrastructure.

We will focus in the following analysis on the particularity of linked property rights, leading to institutional scarcity of water induced by a change in property rights in land, as found in Tajikistan. Applying the patterns will help to disentangle the analytical complexity of resource interlinkages in the agricultural sector.

\subsection{Applying linking patterns to Tajikistan}

The phenomenon of foreign actors securing land for agricultural production has increased substantially in frequency and extent, particularly in (Sub-Saharan) Africa and (South-East) Asia (Von Braun and Meinzen-Dick 2009, Zoomers 2010, Deininger 2011, Deininger and Byerlee 2011, Cotula 2012, Margulis et al. 2013). Based on the latest figures from the Land Matrix ${ }^{4}$ (accessed January

4 The Land Matrix is an open access tool, where data are constantly advancing. It is a useful platform for researchers, NGOs and policy makers to collect and compare various land deals worldwide. For further benefits, but also challenges and critique, see Anseeuw, W., J. Lay, P. Messerli, M. Giger and M. Taylor (2013). “Creating a public 
Table 4: Linking patterns of land and water property rights.

\begin{tabular}{|c|c|c|}
\hline Pattern & $\begin{array}{l}\text { Applied research question addressing changes in the agricultural } \\
\text { water sector }\end{array}$ & $\begin{array}{l}\text { Possibly affected water rights and } \\
\text { customary claims: access (Acc), withdrawal } \\
\text { (W), management (M), exclusion (E), alien- } \\
\text { ation (Al) }\end{array}$ \\
\hline 1. Ecological pattern & Do the natural water conditions require irrigation? & Acc, W, M, E, Al \\
\hline 2. Judicial pattern & $\begin{array}{l}\text { Are water rights explicitly included in the land negotiation or } \\
\text { contract? }\end{array}$ & Acc, W, M, E, Al \\
\hline 3. Use pattern & Does the competition for water and the total uptake increase? & W \\
\hline $\begin{array}{l}\text { 4. Resettlement } \\
\text { patterns }\end{array}$ & $\begin{array}{l}\text { Does the competition of water users increase outside the new } \\
\text { investment farm? }\end{array}$ & Acc, $W$ \\
\hline 5. Land use pattern & Does the change in cropping structure entail a change in irrigation? & w \\
\hline $\begin{array}{l}\text { 6. Conjunctive use } \\
\text { pattern }\end{array}$ & Is there a shift in the share of ground and surface water use? & W, Acc \\
\hline $\begin{array}{l}\text { 7. Infrastructure } \\
\text { pattern }\end{array}$ & $\begin{array}{l}\text { Does the building of new infrastructure or its reconstruction change } \\
\text { the actual irrigation habits of the users? }\end{array}$ & Acc, W, M, E \\
\hline $\begin{array}{l}\text { 8. Governance } \\
\text { pattern }\end{array}$ & Do informal or even formal water governance arrangements change? & Acc, W, M, E, Al \\
\hline
\end{tabular}

Source: Theesfeld (2016).

2015), the completed deals encompass $2.9 \%$ of world's arable land (FAO 2015b). ${ }^{5}$ More recently, the need for a joint analysis of land and water has been recognized in the land grabbing debate. This is shown in the latest discussions that shape the debate about land deals involving access to land with lots of rainfall or irrigation potential (Skinner and Cotula 2011; Woodhouse and Ganho 2011; Anseeuw et al. 2012; Mehta et al. 2012; Franco et al. 2013; Pearce 2013). So far, only a few land grabbing cases are known in Central Asia, mainly in Kazakhstan and Tajikistan. In general, Tajikistan is a country rather unknown for land acquisition research. Media and rather isolated studies (Hofmann 2013) are already addressing the issue of land deals in Tajikistan. Our own fieldwork has provided further insights that where arable land is scarce but water is available, Chinese, Iranian and Turkish investments in land are especially notable, although the land areas involved are much smaller in size than in land deals elsewhere in the world. For instance, Chinese investors have mainly invested in greenhouses in southern Tajikistan and have very much pushed vegetable production. In the future, the lowland regions of Tajikistan are very likely to experience land acquisition, as land is still available to a certain extent and

tool to assess and promote transparency in global land deals: the experience of the Land Matrix.” The Journal of Peasant Studies 40 (3): 521-530.

5 Arable land used for temporary agricultural crops accessed at http://faostat3.fao.org/download/E/EL/E there is an estimated high yield gap, in combination with unclear property rights (Deininger 2011, p. $231 \mathrm{ff}$; Visser and Spoor 2011). For foreign investors, especially, water availability in these lowlands can be the reason to consider Tajikistan a target country. In addition, labour supply in the rural areas is available and technological development is needed. In contrast to Chinese investments, Turkish and Iranian investors in particular might have the potential for a longterm presence due to similar languages and more presence and thus more trust that developed in rural communities over the past years.

The following additional and very focussed case study from the Bokhtar district presents one foreign land acquisition case and serves as anecdotal evidence for the ongoing domestic land rush situation and its impact on the water sector. In 2009 a Chinese investor leased 120 ha land from a collective farm, in order to raise rice and vegetables. This collective farm, with a total of 340 ha, was reorganized in 2006 from a former kolkhoz, yet the kolkhoz manager had remained in charge of the operation. In contrast to what the formal regulations required, the Chinese investor obtained the land not through a lease done by the Land Committee, but via direct negotiations with the collective farm manager, who still has strong ties to the local authorities and remains powerful in the village as a "Kolk- 
hozi” elite ${ }^{6}$ (Boboyorov 2012; Hofman 2013). Although no population was dispossessed of land, this case shows a direct impact on institutional scarcity of land and, as will be shown below, its impact on the water sector. The already small amount of total arable land to be distributed to local farmers has been further limited by this arrangement. Through an informal transaction between the foreign investor and the kolkhoz manager, the foreign investors got former kolkhoz land. By law, this land should have been distributed among the villagers and workers of the former kolkhoz farm.

The following analysis of the interlinkages between the land and the water sector along the lines of the linking patterns, as introduced above, facilitates a systematic description how the Chinese investments in Bokhtar impact on land and water availability.

In general, the ecological pattern means that a large share of foreign or domestic agricultural investment in land shows a pattern where after the investment additional water - besides the annual rainfall - is required for efficient production. Even in countries with at-first-sight favourable natural water conditions such as Tajikistan, the new cropping or production system (a land use change or an intensification of production) can depend on additional water input, from ground or surface water. Irrigation can help to avoid vulnerability to the variations in water supply which if not protected against could lead to highly insecure rate of returns on investments. Due to the low precipitation (average annual rainfall $150-290 \mathrm{~mm}$ ) and very dry summer months, irrigation by ground or surface water is inevitable for all farms in the case study area likewise for the Chinese rice and vegetable farm. Given that fact, without considering any interference in technical or organizational components of the irrigation system, the ecological pattern signifies already that an impact on the property rights on water is very likely.

The judicial pattern follows the property rights disentangled by Schlager and Ostrom (1992). It has to be checked whether access, withdrawal, management, exclusion or alienation rights on water are explicitly mentioned in the land buying or leasing contract, or have been part of the negotiation. A starting point is to find out which kind of water rights are vested with the state, which is often the entity negotiating the land deals. The formulation of agreements in the water sector is often subordinated and left to the local actors. Skinner and Cotula (2011) and Woodhouse (2012) investigated land deals and

6 "kolkhozi elites" are referred to as former state- or collective farm owners, who still remain powerful or even perform leadership tasks in their specific community. found that investors frequently want to secure water rights formally, and usually get them. The long-term leases on state-owned land worldwide now more and more allocate water rights to foreign investors, too. The rights allocated range from unrestricted access to canal and ground water to access with conditions regarding dry season crops. Water payments may be fixed through volumetric billing, or left to be negotiated per hectare depending on the type of irrigation used. Even when a land contract makes no specific reference to water, water may still form part of the deal, as governments may agree to invest in water-related infrastructure (Skinner and Cotula 2011), or customary access claims to a river can simply become invalid, because the route to the river across land now owned by an investor can be denied.

The judicial pattern in this Tajik case not only encompasses the joint land and water access provided, even if informally, by this acquisition. It also reveals the powerful position of the collective farm in terms of decision-making, even towards foreigners. As this has been an informal land deal, it is also worth noting that the water rights were not officially re-distributed via authorities. Instead they were directly negotiated between the collective farm manager and the Chinese investor.

In regions where no resettlement or dispossession of land is involved, simply the fact that investors enter the arena leads most often to an increase in the number of farmers using irrigation (Theesfeld 2016). But what is more important is the fact that the investor is not only one additional, but often a more intensive water user. This is often due to more advanced water access or use techniques. Physical water availability is under more pressure and resource scarcity may increase. Likewise, the quality of irrigation water in the neighbouring and particularly downstream farmland areas might be diminished. This use pattern stands for the strongest possible direct impact on water scarcity.

In the case study, the land from the collective farm formerly used primarily for cotton (70 \% of the area involved) was used by the Chinese to produce rice ( $80 \%$ of the area) and vegetables (20\% of the area). According to estimations by Aldaya et al. (2010, p. 31) rice production in Tajikistan has a higher total water requirement (with an additional $300 \mathrm{~m}^{3} /$ ha of total crop water use) than cotton ${ }^{7}$. Although the cultivated area did not increase in total, the total water uptake and thus competition for water access and withdrawal rights among all water users in the area increased, creating physical scarcity. This also adds to in-

7 The data are based on estimations by Aldaya et al. (2010) and present the average for the country's cotton and rice total crop water use. 
stitutional scarcity, if not all former users receive adequate access. This is classified as the use pattern (see Table 4).

The most stand-alone pattern of all other patterns is the land use pattern. It describes a process which has a direct impact on water availability. This means, no matter whether the new production is on humid fertile soils, or on dry soils that require irrigation, whether water rights have been mentioned in the land deal or not, whether the land has been in fact abandoned or occupied by other farmers, investors often favour more water-intensive crops (Ismar 2013, p. 287) such as sugar beet or rice (Pearce 2013) or monoculture forest plantation of pines or eucalyptus which extract large amounts of water (Kruchem 2013, p.151). In such a situation one can assume a change in property rights in water as a direct consequence. ${ }^{8}$

In the Tajik case, the change from cotton to rice resulted not only in a higher water demand but also in a different organization of water flow and a necessity for improved quality of water for rice production. Rice, in contrast to cotton, depends on continuous water flow, especially during the dry months of the year. Cotton depends on very precise individual irrigation turns. In rice production, additional water is needed for land preparation, for the flooding itself and to protect the plants (FAO 2013). In addition, rice needs enhanced water quality in terms of low salinity level. But salinity in particular is a major problem in the irrigated areas of Tajikistan, where inadequate drainage systems and waterlogging are boosting salinization (UNDP 2003). Thus, access and withdrawal rights of all adjacent farmers including those of the household plots are affected, because adapted irrigation schedules are enforced that give first priority to continuous water supply for the plots cultivated with rice. In irrigation catchment areas where rice production increases, this continuous need for water makes water sharing much more difficult compared to a system where every water user gets a certain time slot assigned in which to open the canals and take how much is needed to conduct furrow irrigation. Under this regime, household plot famers cannot count on a filled canal when their irrigation turn is due.

One side-effect of a planned land use change accompanying the investment in land might be additional

8 But not every severe land use change does lead to a big change in the property rights on water. The kind of production involved is of course crucial for the impact on the water sector. In Australia, where about $10 \%$ of the total global grabbed-land activity is happening, most of the grabbed land is used for livestock production. This land use change - although large in size - involves only a small amount of water grabbing Rulli, M. C., A. Saviori and P. D’Odorico (2013). “Global land and water grabbing." Proceedings of the National Academy of Sciences 110 (3): 892-897 investments in the infrastructure (irrigation, drainage, roads). This infrastructure pattern is of course a very crucial one and represents a direct impact on water availability. With a change in the infrastructure and technology, almost every user faces a change in de-facto water access and withdrawal rights. Depending on the individual location related to the infrastructure or canal outlet, the users might have at their disposal more or less water in various quantities and qualities, at different times, at different prices. Infrastructure investment does not only comprise big dams, reservoirs or canal system construction, but also irrigation techniques such as drip or sprinkler irrigation, or even computer-driven water regulation to control humidity in greenhouses. Usually, the management rights change along with a reconstruction of the infrastructure. More effective technical options to exclude users may lead to water scarcity for actors who had previously secure access to water.

Compared to rain-fed production systems, or the gravity-flooding of fields, the investment in canal systems and the upgrade in irrigation techniques allows primarily the investor, rather than other agricultural water users, to use irrigation water for a second or more harvesting season and crop rotation. Crop production and water acquisition is becoming less season dependent. This may change the actual withdrawal and access rights and with this the physical water availability in the whole water and irrigation catchment area (Theesfeld 2016).

In many regions of Tajikistan, the big farms within their watershed are the major force in maintaining and investing in off-farm irrigation infrastructure. This however makes the smaller farmers dependent on the actions of the bigger farms. There is empirical evidence that to achieve the continuous water flow for rice production and efficient water use for vegetable production, the investor in Bokhtar had to make three types of changes in the irrigation infrastructure. The Chinese farm has invested first in off-farm infrastructure, by rebuilding an upstream pump. This ensured that water from the river flowed to the primary canal and further via a secondary canal to the plots of the farm. The Chinese additionally invested in the primary canal system. Surrounding small farms and households benefited on the one hand in terms of water availability and access, but on the other hand, they were totally dependent on the irrigation schedule for rice set by the Chinese. Consequently, outside the rice season, water flow was not continuous anymore. In interviews, farmers reported that in the water-scarce and highly water-supply-variable time of the year, surplus water to downstream farmers was limited or even non-existent. Thus with the off-farm investments, access, management and withdraw- 
al rights were affected. Another large-scale investment in infrastructure by the Chinese was done at the inter-farm level, between the collective farm and the investment area of the Chinese. The collective farm benefited from the improved water flow, which likewise strengthened the de-facto water access and withdrawal rights. The third investment was realized at the on-farm level, by building new on-farm canals and introducing drip irrigation to the vegetable fields. Investments in adequate drainage canals, however, were missing.

Getting involved in irrigation infrastructure reconstruction and management leads in the long run naturally to an involvement in water governance by the producers who are expanding their operations. Water acquisition is not only about the capturing of the water itself, but also about taking over the power to decide how it will be used (Franco et al. 2013). A previously informal or even formal agricultural water governance system may change. As regards the governance pattern, the governance system may not only be composed of the new water user association, but also specific decisions and rule changes on how to elect the chairman, on how to set up irrigation turns, on new measures of charging water fees, on new sanctioning systems, or on new workforce requests for maintenance. If the governance systems are not adequate, farmers can face an institutional water scarcity, despite physically plentiful water availability. Although there has not been any observed change in formal and informal governance structures, this case likewise underlines the significance of the governance pattern. The absence of change in the governance pattern is in itself an important element to consider. The very limited options to change or reform the governance mechanisms could be seen as one reason why the Chinese left after three years in operation. It appears that the investment did not return the expected output in increased land productivity also due to inflexible governance mechanisms. The interviews in the village have shown that for the Chinese it was likewise not possible to change the local power structures and to intervene in any governance mechanisms to reduce the institutional water scarcity either for the watershed or for their own farm. The general unsatisfactory national operation and maintenance of irrigation infrastructure in Tajikistan limited the Chinese incentive to invest further in water infrastructure. The overall water uptake requirement of the new rice fields could not be addressed by the Chinese investments alone. In 2012 the Chinese cancelled the land leasing contract with the collective farm before it expired. According to conversation in the village, ongoing water problems due to poor water infrastructure were another reason the Chinese left the area. After the Chinese left, the manag- er of the collective farm took back the land and took over the Chinese on-farm irrigation system. The de-facto water rights for the collective farm thus were strengthened in terms of management and also access rights.

The case study exemplifies how, after carefully disentangling the property rights structures along the lines of the linking patterns, it is possible to determine the impacts of this land acquisition. The land use change, combined with requirements for water use and the investments in the infrastructure, made local water users quite dependent on the water schedule of the powerful investor. That, in turn, led to an institutional scarcity of water resources.

\subsection{Interrelations between structural change and resource scarcity}

In the following, we explore on the other two dimensions of resource-induced structural change in the agricultural land and water sector. The relations between structural change and resource scarcity are not unidimensional but rather interrelated. On the one hand, scarcity of natural resources and particularly institutional scarcity affects agricultural structural change. On the other hand, structural change in the agricultural sector has, in turn, implications for resource availability. The latter aspect can be shown with the results of the post-socialist land reform and of the increase in domestic and foreign large-scale land acquisitions, where we observed a change in the property rights in land. Rights guaranteed by the state and customary claims in land have a heavy impact on the de-facto property rights in water, as well. The resulting physical, but also institutional, scarcity of water can thus be both a result and a driver of structural change in the agricultural sector.

For the second dimension (Table 3) we identified for instance the impact of institutional scarcity of water on the production decision of farmers. When water access and withdrawal rights are perceived as insecure and unpredictable, a change of cropping patterns to less water-intensive crops is expected. Besides other economic reasons, this is for instance represented by the land use change in Tajikistan from cotton to wheat and other crops. Data from an agricultural advisory service (Soghd Agroserv Consulting 2012) has shown that one of the main reasons for the latter change in the case study area was that wheat requires less irrigation water. Berbel and GómezLimón (2000) show in their analysis of the impact of water-pricing policy in Spain the same features of farmers' dependence on irrigation water. Farmers cannot adopt water-saving technologies without affecting crop distribution. The crops - in order to provide maximum yield - re- 
quire a certain amount of water, sometimes even at a certain time in the growing season or with a certain quality. According to Berbel and Gómez-Limón (2000), farmers' response to less water availability is to change crop plans by growing crops that consume less water. Some non-irrigated crops may even appear in the new decision plan. Yet, introducing less profitable crops as substitutes for more valuable water-demanding crops significantly decreases farmers' incomes. Water-demanding crops such as cotton (or sugar beet, onions, corn) are often replaced by less labour-demanding and more mechanized crops such as cereals and sunflowers (Berbel and Gómez-Limón 2000). Another consequence of the substitution of crops is thus a significant loss of employment both directly on farms and indirectly in processing facilities (Berbel and Gómez-Limón 2000). In the long run this is a strong driver for structural change in the agricultural sector.

Another argument can be drawn from the fact that not every farmer has equal access to water resources. We conclude that those facing limited water access have fewer choices in crop diversification. The reduction in the number of crops available for farming results in a smaller number of alternatives and greater technical and economic vulnerability of the agricultural sector. Without the option to diversify, farmers are severely exposed to market and ecological risks, and eventually abandon the land and agriculture. They switch to other sectors or migrate - , in fact, fostering substantial agricultural structural change.

In contrast, farmers with reliable water access can further concentrate on water-intensive, high-input, irrigated agriculture. Land use change increases, towards profitable but often highly water-dependent cash crops or monoculture. Profitable and competitive farming allows farmers or other investors to buy or lease more land and to expand - furthering the land concentration process.

The third dimension represents the impact of the prevailing structural changes on the governance and the provisioning of infrastructure, with implications for the man-made availability of the natural resources. With privatization and land reform, right after the socialist period, the largely designed socialist-style irrigation infrastructure did not correspond to the plot sizes and dispersed distribution of plots of the newly evolving smaller-scale farmers and tenants. New outlets and tertiary canal systems needed to be built to reach all plots. With any investment in infrastructure, however, the property rights of users also change. Infrastructure projects entail water rights redefinition, often disadvantaging those with previously informally established rights (Beccar, Boelens and Hoogendam 2002, p.11).
With the latest observed changes in Central Asian's agricultural structures we expect larger farms and land concentration in the hands of fewer farmers in Tajikistan (Visser and Spoor 2011). Consequently, the requirements for providing natural input resources - like water - to the farmers will change again. With larger farm and plot sizes, the infrastructure will have to be adjusted again. Based on studies of power asymmetry among head and tail-end farmers sharing one irrigation canal (Theesfeld 2004), expanding farmers build larger-scale infrastructure to deliver more water. The new system simultaneously delivers more water to certain plots and leaves behind neighbouring, tail-end or not-connected farmers with an institutional scarcity of water.

Land concentration and bigger farm sizes as an accelerating phenomenon require a workforce with different skills, to handle the increased mechanisation and standardization of production processes that facilitate management of larger farms. Mechanisation needs in turn lead to different crop decisions and land use change (Van der Ploeg et al. 2015). The water initially available might not be suitable for the new crops, which may require additional irrigation - increasing the competition for irrigation water (Rulli et al. 2013; Ismar 2013, p. 287).

\section{Conclusion}

We consider the natural resources jointly, because the resources are linked not only bio-physically but institutionally via the formal and informal property rights in place. With a property rights change in one resource, due to bio-physically interrelations the property rights to another resource may become restricted or ineffective - whether or not that was intended. This institutional scarcity of natural resources comes into play at a point prior to optimal resource distribution and use. A solid study of not only physical, but also institutional relationships between the natural resources land and water allows us to make more reliable predictions about structural change in the agricultural sector induced by institutional scarcity. Such changes include being forced to switch to less water intensive crops, leading to a land use change.

Further, we assume that in contrast to the current agricultural structure in Tajikistan as described in Section 2, scarce land and water resources, in particular - the main natural input factors into agriculture - will promote the development of land concentration, i.e. an increase in farm size and decrease in the number of farms in the fu- 
ture. This is a development well under way in most of the Western developed countries (van der Ploeg 2015).

Both reforms in the land and water sector, and with this the institutional scarcity of land and water, may lead to agricultural structural change. Overall, we aim neither to judge whether the observed development is good nor to determine whether obstacles to development need to be reduced and how. Yet, it can be recognized that at the present time, Tajikistan's agricultural production is insecure and as a result, profit is unreliable. Overall, very low wages and salaries can be observed in agriculture, hunting, and forestry ${ }^{9}$ (TAJStat 2014) over the past several years. This development in the agricultural sector has wider implications for social development. Insecure production as well as continuing low incomes are challenging the rural areas and the rural societies tremendously. For the young Tajik rural population, one "exit strategy" to deal with problems in rural areas is to migrate, especially to Russia. In addition to the many complex reasons for rural migration, including the high unemployment rates and the harsh agricultural sector, the unpredictability of agricultural production is an important factor causing many people to migrate to Russia. High out-migration rates are demonstrated by the numbers of the migrant remittance inflow which show a dramatic increase. In 2014 the share of remittances in GDP amounted already to $41.7 \%$ (World Bank 2016) ${ }^{10}$. Such migration movements tend to appear when the agricultural sector cannot buffer the economic transformation's social hardships, as occurred in many Eastern European post-socialist countries in the first years of the transition. Out-migration has also wider implications for rural societal development. In the long run, this shift in rural societies can further challenge the land and water sector, especially from an institutional perspective. An ominous fact is that most of the remittances received at farm household level are not returned to the development of the agricultural sector - for instance, to irrigation infrastructure development.

9 Wages reported for the September 2014 period are the lowest in the last decade (290.12 somoni). For the fishery sector 453.75 somoni have been reported as the September 2014 average salary. The exchange rate as of 03.01.2016: 1 Euro $=7.60$ Somoni (TJS).

10 Globally, this is the highest share of remittances in GDP, followed by the Kyrgyz Republic (a share of $30 \%$ in GDP) and Nepal (a share of $29 \%$ in GDP) WorldBank (2016). "World Bank Data: Personal remittances, received (\% of GDP).” Retrieved 03.01.2016, 2016, from http:// data.worldbank.org/indicator/BX.TRF.PWKR.DT.GD.ZS.

\section{References}

Akramov, K. T. and G. Shreedhar (2012). “Economic development, external shocks, and food security in Tajikistan.” IFPRI Discussion Paper 1163. Washington, D.C.: International Food Policy Research Institute (IFPRI).

Aldaya, M. M., G. Munoz and A. Y. Hoekstra (2010). “Water Footprint of Cotton, Wheat and Rice Production in Central Asia." Value of Water Research Report Series. Delft, UNESCO-IHE Institute for Water Education. 41.

Anseeuw, W., J. Lay, P. Messerli, M. Giger and M. Taylor (2013). "Creating a public tool to assess and promote transparency in global land deals: the experience of the Land Matrix." The Journal of Peasant Studies 40 (3): 521-530.

Anseeuw, W., A. L. Wily, L. Cotula and M. Taylor (2012). Land Rights and the Rush for Land: Findings of the Global Commercial Pressures on Land Research Project. Rome, International Land Coalition.

Beccar, L., Boelens, R. and P. Hoogendam (2002). "Water rights and collective action in cummunity irrigation." Water rights and empowerment, R. Boelens and T. Hoogendam (eds.) Van Gorcum, Assen, The Netherlands, 1-21.

Berbel, J. and J. A. Gómez-Limón (2000). "The impact of water-pricing policy in Spain: an analysis of three irrigated areas." Agricultural Water Management 43 (2): 219-238.

Boboyorov, H. (2012). "Personal networks of agricultural knowlege in cotton-growing communities of Southern Tajikistan." Demokratizatsiya 20 (4): 409-435.

Chavas, J.-P. (2001). Chapter 5 Structural change in agricultural production: Economics, technology and policy. Handbook of Agricultural Economics, Elsevier. Volume 1, Part A: 263-285. Amsterdam.

Cotula, L. (2012). "The international political economy of the global land rush: A critical appraisal of trends, scale, geography and drivers." Journal of Peasant Studies39 (3-4): 649-680.

Deininger, K. (2011). "Challenges posed by the new wave of farmland investment." The Journal of Peasant Studies 38 (2): 217-247.

Deininger, K. and D. Byerlee (2011). Rising global interest for farmland. Can it yield sustainable and equiable benefits? Washington, D.C., World Bank.

FAO (2013). Aquastat: Irrigation in Central Asia in Figures. Aquastat Survey - 2012. Rome, FAO Land and Water Division.

FAO (2015a). “AQUASTAT Main Database.” Retrieved 01.12.2015, from http://www.fao.org/nr/water/aquastat/data/query/ index.html?lang=en.

FAO (2015b). “FAOSTAT Database: Agri-Environmental Indicators, Land.” Retrieved 03.01.2016, from http://faostat3.fao.org/ download/E/*/E.

FAO (2015c). “FAOSTAT Database: Population.” Retrieved 03.01.2016, from http://faostat.fao.org/site/550/default. aspx\#ancor.

Franco, J., L. Mehta and G. J. Veldwisch (2013). “The Global Politics of Water Grabbing.” Third World Quarterly 34 (9): 1651-1675.

Gehrigk, F., T. Herzfeld and I. Theesfeld (2013). Farmers' perceptions of land and water property rights: Discrepancies between de jure and de facto rights in Tajikistan. Natural resource use in Central Asia: Institutional challenges and the contribution of capacity building. Giessen. 
Hagedorn, K. (2008). “Particular requirements for institutional analysis in nature-related sectors." European Review of Agricultural Economics 35 (3): 357-384.

Hofman, I. (2013). "Understanding forms of contention in the post-Soviet setting: rural responses to Chinese land investments in Tajikistan." LDPI Working Paper, Land Deal Politics Initiative (LDPI).

Hofman, I. and O. Visser (2014). "Geographies of transition: The political and geographical factors of agrarian change in Tajikistan." IAMO Discussion paper 151. Halle (Saale).

Ismar, J. (2013). How to govern the global rush for land and water? Handbook of Land ans Water Grabs in Africa. T. Allan, M. Keulertz, S. Sojamo and J. Warner. London and New York, Routledge: 286-298.

Kirschke, D., M. Odening, A. Häger and O. Mußhoff (2007). "Strukturwandel im Agrarsektor." HU-Spektrum 14 (1): 24-31.

Knickel, K. (1990). "Agricultural structural change: Impact on the rural environment." Journal of Rural Studies 6 (4): 383-393.

Kruchem, T. (2013). Land and Water. Frankfurt am Main, Brandes \& Apsel Verlag.

Lerman, Z. (2012). "Rural Livelihoods in Tajikistan: What Factors and Policies Influence the Income and Well-Being of Rural Families," in: V. Squire: Rangeland Stewardship in Central Asia: Balancing Improved Livelihoods, Biodiversity Conservation and Land Protection Springer, Dordrecht, pp.165-187.

Mandler, A. (2013). "Knowledge and Governance Arrangements in Agricultural Production. Negotiating the Access to Arable Land in Zarafhsn Valley, Tajikistan.” ZEF Working Paper (106), Bonn.

Margulis, M. E., N. McKoen and S. M. Borras , Jr. (2013). "Land Grabbing and Global Governance: Critical Perspectives." Globalizations 10 (1): 1-23.

Mbereko, A., Mukamuri, B., and M. Chimbari (2015). "Exclusion and contest over wetlands used for farming in Zimbabwe: a case study of broad-ridge and broad-furrow tillage system on Zugwi Vlei." Journal of Political Ecology 21, 322-338

Mehta, L., G. J. Veldwisch and J. Franco (2012). "Introduction to the Special Issue: Water Grabbing? Focus on the (Re)appropriation of Finite Water Resources." Water Alternatives 5 (2): 193-207.

Ostrom, E. (1992). Crafting Institutions for Self-Governing Irrigation Systems. ICS Press. Institute for Contemporary Studies, San Francisco.

Pearce, F. (2013). "Splash and grab: The global scramble for water." NewScientist 2906; 4 March 2013, Retrieved 16.02.2016 from http://www.newscientist.com/article/mg21729066.400splash-and-grab-the-global-scramblefor-water.html

Ribot, J.C., Peluso, N.L., 2003. A Theory of Access. Rural Sociology 68 (2): 153-181.

Robinson, S. and T. Guenther (2007). "Rural Livelihoods in Three Mountainous Regions of Tajikistan." Post-Communist Economies 19 (3): 359-378.

Robinson, S., I. Higginbotham, T. Guenther and A. Germain (2008). Land Reform in Tajikistan: Consequences for Tenure Security, Agricultural Productivity and Land Management Practices. The Socio-Economic Causes and Consequences of Desertification in Central Asia. R. Behnke, Springer Dordrecht: 171-203.

Rulli, M. C., A. Saviori and P. D’Odorico (2013). “Global land and water grabbing." Proceedings of the National Academy of Sciences 110 (3): 892-897.

Sadoff, C., K. Kemper and D. Grey (2006). "Calming global waters: managing a finite resource in a growing world.” Global issues for global citizens : an introduction to key development challenges. V. Bhargava, World Bank, Washington D.C. 265-284.

Schlager, E. and E. Ostrom (1992). "Property-Rights Regimes and Natural Resources: A Conceptual Analysis.” Land Economics 68 (3): 249-262.

Skinner, J. and L. Cotula (2011). Are land deals driving "water grabs"? IIED Briefing. London, IIED.

Soghd Agroserv Consulting (2012). Internal report on Crop Water Requirements in Tajikistan.

Specht, J. W., Katrin; Häring, Anna Maria; Braun, Charis Linda (2013). Wandel im ländlichen Raum: Von Wandlungsprozessen zu neuen Kompetenzbedarfen Wandel Wissen Wertschöpfung. Eberswalde. Eberwalde.

Swinnen, J. F. M. and S. Rozelle (2006). From Marx and Mao to the market: the economics and politics of agricultural transition. Oxford; New York, Oxford University Press.

TAJStat (2012). МИНТАК์АњОИ љУМњУРИИ ТОљИКИСТОН (TAJSTAT) (translation: Regions of Tajikistan). Dushanbe, Tajikistan.

TAJStat (2014). "Food Security and Poverty." Tajikistan. Dushanbe, Tajikistan. 3.

TAJStat (2015) НИШОНДИњАНДАњОИ ГЕНДЕРї ОИД БА ФАЪОЛИЯТИ ИСТЕЊСОЛИИ ХОЉАГИЊОИ ДЕЊК์ОНЇ ДАР СОЛњОИ 2009 - 2014 (translation: Gender-Indicators in the agricultural sector 2009 - 2014). Dushanbe, Tajikistan.

Theesfeld, I., 2004. "Constraints on Collective Action in a Transitional Economy: The Case of Bulgaria's Irrigation Sector.” World Development 32 (2): 251-271.

Theesfeld, I. (2015). „Das komplexe Geflecht von Land- und Wasserraub.“ KOMPASS Das Themenmagazin des Weltfriedensdienst.e. V. W. e. V. (WFD): 13-14

Theesfeld, I. (2016). "The Impacts of Liberalized Land Markets on the Resource Water: A Property Rights Approach.” Schriften der Gesellschaft für Wirtschafts- und Sozialwissenschaften des Landbaus e. V. Landwirtschaftsverlag: 261-270.

UNDP (2003). “Tapping the potential. Improving water management in Tajikistan.” National Human Development Report. New York, United Nations Development Programme.

USAID (2014). AgTCA Tajikistan - Agricultural Technology Commercialization Assessment. United States Agency for International Development - Enabling Agricultural Trade (EAT) project report. Retrieved 16.02.2016 from http:// eatproject.org/portfolio-tca. $\mathrm{html}$, last accessed.

van Atta, D. (2009). "White Gold or Fool's Gold? The Political Economy of Cotton in Tajikistan." Problems of Post-Communism 56 (2): 17-35.

van der Ploeg, J.D., Franco, J.C., Borras, S.M. (2015). "Land concentration and land grabbing in Europe: a preliminary analysis." Canadian Journal of Development Studies/Revue canadienne d'études du développement 36 (2): 147-162.

Verdery, K. (2003). The vanishing hectare: property and value in postsocialist Transylvania. Ithaca, Cornell University Press.

Visser, O. and M. Spoor (2011). "Land grabbing in post-Soviet Eurasia: the world's largest agricultural land reserves at stake.” Journal of Peasant Studies 38 (2): 299-323.

Von Braun, J. and R. Meinzen-Dick (2009). "Land grabbing” by foreign investores in developing countries: risks and oppertunities." IFPRI Policy Brief 13: 1-9. Washington, D.C.: International Food Policy Research Institute (IFPRI). 
Walsh, C. (2004). “Aguas Broncas: The Regional Political Ecology of Water Conflicts in the Mexico-U.S. Borderlands." Journal of Political Ecology 11: 43-58.

Wegerich, K., 2002. "Natural drought or human made water scarcity in Uzbekistan?" Central Asia and the Caucasus 2 (14): 154-162.

Woodhouse, P. (2012). "Foreign Agricultural Land Acquisition and the Visibility of Water Resource Impacts in Sub-Saharan Africa." Water Alternatives 5 (2): 208-222.

Woodhouse, P. and A. Ganho (2011). Is Water the Hidden Agenda of Agricultural Land Acquisition in sub-Saharan Africa? International Conference on Global Land Grabbing. Sussex, Land Deal Politics Initiative (LDPI).
World Bank (2012). “Tajikistan - Farmer and farm worker perceptions of land reform and sustainable agriculture." Washington, DC: World Bank. Retrieved 16.02.2016 from http:// documents.worldbank.org/curated/en/2012/06/16461734/ tajikistan-farmer-farm-worker-perceptions-land-reform-sustainable-agriculture.

WorldBank (2016). “World Bank Data: Personal remittances, received (\% of GDP).” Retrieved 03.01.2016, 2016 from http:// data.worldbank.org/indicator/BX.TRF.PWKR.DT.GD.ZS.

Zoomers, A. (2010). "Globalisation and the foreignisation of space: seven processes driving the current global land grab." Journal of Peasant Studies 37 (2): 429-447. 